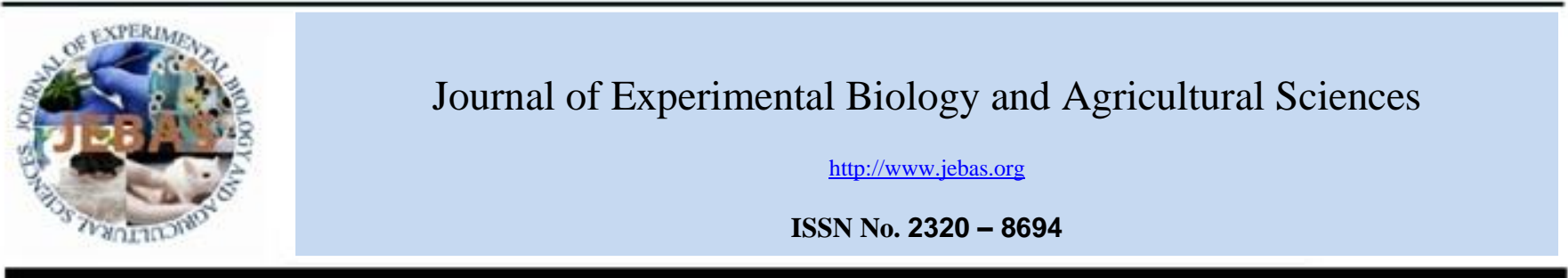

\title{
CONCURRENT INFECTION OF PESTES DES PETITS RUMINANTS AND ENTEROTOXAEMIA IN AN ORGANIZED GOAT FARM
}

\author{
M. Latha Mala Priyadharshini, K. Manimaran*, K.Karthik, R. Mahaprabhu, Parimal Roy \\ Central University Laboratory, Centre for Animal Health Studies, TANUVAS, Madhavaram Milk Colony, Chennai-600 051, Tamil Nadu State.
}

Received - October 13, 2017; Revision - December 14, 2017; Accepted - February 04, 2018

Available Online - February 20, 2018

DOI: http://dx.doi.org/10.18006/2018.6(1).204.210

KEYWORDS
PPR
Enterotoxaemia
RT-PCR
Goat

\begin{abstract}
An unknown disease outbreak was reported in Solankurinchi village of Madurai district in Tamil Nadu, among Tellichery and Kanni breeds of goats wherein an investigation was undertaken. Out of the total 520 animals $80 \%$ were Tellichery goats and $20 \%$ was native Kanni goats. About $20 \%$ of both the breeds were young ones. The clinical signs observed among the affected animals were high fever, anorexia, reduced feed intake, emaciation, profuse diarrhoea, dehydration, bilateral muco-purulent nasal discharge, sudden death, in-coordination and convulsions in kids of about 6-8 months, abortion and still birth among pregnant goats. Mortality occurred to the extent of $12.5 \%$ to $22.5 \%$ between the age groups of 4-7 months in Tellichery goats, while only $1 \%$ of the Kanni goat kids exhibited clinical signs. Among Tellichery adults mortality was $0.6 \%$ whereas no adult Kanni goats died. Stillbirths accounted for $1.6 \%$ and abortion was upto $1 \%$ in Tellichery does. Upon necropsy, congested, oedematous pleural surface with rib marking on lung was observed in the thoracic cavity. The abdomen was distended with curdled milk and abomasal mucosa contained diffuse pinpoint black pigmentation scattered all over its surface. In the brain haemorrhage and few petechae were noticed. Samples were collected for laboratory diagnosis and investigation was done to rule out Enterotoxaemia by the Biological assay and a RT-PCR
\end{abstract}

* Corresponding author

E-mail: maranvet@yahoo.com (K. Manimaran)

Peer review under responsibility of Journal of Experimental Biology and Agricultural Sciences.

Production and Hosting by Horizon Publisher India [HPI] (http://www.horizonpublisherindia.in/).

All rights reserved.
All the article published by Journal of Experimental Biology and Agricultural Sciences is licensed under a Creative Commons Attribution-NonCommercial 4.0 International License Based on a work at www.jebas.org.

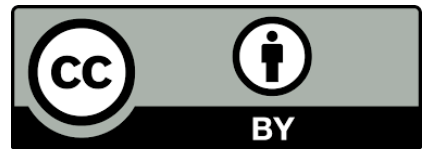


for confirmation of PPRV infection as the primary cause of this disease outbreak. Vaccination is commonly followed worldwide to prevent both the disease but still occurs in unvaccinated flocks and following vaccine failure.

\section{Introduction}

India is an agrarian nation with a considerable population having agriculture as their occupation, where livestock plays an important role. But for marginal or landless labourers and pastoral farmers sheep and goats play a pivotal role for their socio-economic upliftment. The total Goat Population in the country is 135.17 million numbers in 2012. The sheep and goat population in Tamil Nadu is 172.66 lakhs (All India Report, 2012). The greatest concern to sheep and goat industry is the prevalence of deadly infections, their prevention and management strategies practiced. Worldwide important infectious diseases of sheep and goats are Blue tongue, Pox, Peste des petits ruminants (PPR), Lenti virus and enterotoxaemia. PPR is a devastating infectious disease caused by the PPR virus, a member of the morbillivirus genus of the family Paramyxoviridae. PPR (peste des petits ruminants) is a most important viral disease of goat capable of heavy mortality and commonly called as goat plague. The PPRV genome consists of a single stranded negative sense RNA of approximately 16 kilobases containing six genes, encoding 6 structural and 2 non structural proteins. The virus exists as a single serotype. In India the disease was first reported in Arasur village in Villapuram district, Tamil Nadu (Shaila et al., 1996). The economic losses due to PPR in goats and sheep is Rs 8895.12 crores, of which Rs. 5477.48 crores loss due to PPR in in goats while Rs. 3417.64 crores loss due to PPR in sheep (Singh et al., 2014).

Clostridium perfringens is a ubiquitous entero-pathogen (Ferrarezi et al., 2008) commonly seen in well fed animals (Jemal et al., 2016). The morbidity rate does not exceed $10 \%$ of the herd strength, but its lethality usually kills $100 \%$ of the affected animals. C. perfringens is prevalent throughout the world and possess different toxins in the arsenal to cause disease in different species of animals. Clostridium spp. are gram positive, nonmotile, rod shaped, anaerobic bacteria distributed in the soil and digestive tract of animals (Sawires \& Songer, 2006; Uzal et al., 2014). The $C$. perfringens is a heterogenous group of organism with respect to their metabolic by- products, toxins and pathogenic potential and is divided into five types from A to $\mathrm{E}$ based on lethal toxins (alpha, beta, epsilon and iota) (Smedley \& McClane, 2004). Types B, C and D are commonly associated with disease in domestic animals and are one of the most important causes of sudden death in goats of different ages. However, no single strain produces this entire toxin panoply.
C. perfringes type $\mathrm{C}$ and $\mathrm{D}$ are normal commensals of the gut micro-flora of healthy sheep and goats and thus poses the risk of infected animals entering the food chain (Wojdat et al., 2006) and producing histo-toxic and enteric diseases in both humans and other animals. A primary PPR viral infection causes remarkable immune-suppression that leads to secondary infections with high morbidity and mortality. The study was undertaken to know about the clinico-pathological findings in goats during a natural outbreak of concurrent viral and bacterial infection and detection of the viral genome in tissues by PCR and the bacterial toxin by biological assay.

\section{MATERIALS AND METHODS:}

\subsection{Flock Investigation}

The flock had at the time of first death, a total of 520 goats $(80 \%$ Tellichery \& $20 \%$ Kanni breed). There was no proper vaccination history for the animals. The flock was managed in semi intensive system and animals were housed in sheds having slatted flooring and fed with concentrates and roughages. Table 1 shows the animal population in the affected farm

Table 1 Breed and sex, age wise categorization of goats in the affected population

\begin{tabular}{|ccccccc|}
\hline $\begin{array}{c}\text { S. } \\
\text { No }\end{array}$ & \multicolumn{2}{c}{$\begin{array}{c}\text { Tellichery } \\
\text { breed }\end{array}$} & & \multicolumn{2}{c|}{ Kanni breed } & $\%$ \\
\hline 1 & Bucks & 36 & 10.81 & Bucks & 12 & 11.54 \\
\hline 2 & Does & 297 & 89.19 & Does & 72 & 69.23 \\
\hline 3 & Kids & 83 & 20 & Kids & 20 & 20 \\
\hline 4 & Total & $\mathbf{4 1 6}$ & 80 & Total & 104 & 20 \\
\hline
\end{tabular}

\subsection{History and clinical signs}

In a herd of 520 heads, kids between the age group of 3-6 months suddenly started to die and within a short span of one month 40 kids had died in January- February of 2015. Females were affected more than the males. Some animals showed diarrhoea, muco-purulent bilateral nasal discharge, recumbency, opisthotonous, convulsion and internal vocalizing. Pregnant animals aged between 1 to 2.5 years were reported to have still 
Table 2 Details of the disease outbreak pattern in the farm

\begin{tabular}{|c|c|c|c|c|c|c|}
\hline $\begin{array}{l}\text { S. } \\
\text { No }\end{array}$ & $\begin{array}{l}\text { Time } \\
\text { period }\end{array}$ & $\begin{array}{l}\text { Kids } \\
\text { died }\end{array}$ & $\begin{array}{l}\text { Mortality } \\
\text { rate- \% }\end{array}$ & $\begin{array}{l}\text { Age group } \\
\text { (months) }\end{array}$ & $\begin{array}{l}\text { Adults } \\
\text { T/K }\end{array}$ & Symptoms \\
\hline 1. & $\begin{array}{c}3^{\text {rd }} \text { week of } \\
\text { January }\end{array}$ & 6 & $15 \%$ & $3-31 / 2$ & - & $\begin{array}{c}\text { Anorexia, High Fever, Diarhoea, } \\
\text { Nasal discharge }\end{array}$ \\
\hline 2. & $\begin{array}{l}4^{\text {th }} \text { week of } \\
\text { January }\end{array}$ & 9 & $22.5 \%$ & $5-51 / 2$ & $\begin{array}{l}\text { K-mild nasal } \\
\text { discharge } \\
\text { Anorexia }\end{array}$ & $\begin{array}{l}\text { Diarrhoea, Sore mouth, Weight } \\
\text { loss, Nasal \& ocular discharge }\end{array}$ \\
\hline 3. & $\begin{array}{l}1^{\text {st }} \text { week of } \\
\text { February }\end{array}$ & 5 & $12.5 \%$ & 7 & - & $\begin{array}{c}\text { Mucopurulent bilateral nasal } \\
\text { and ocular discharge, ulcers, } \\
\text { debility }\end{array}$ \\
\hline 4. & $\begin{array}{l}2^{\text {nd }} \text { week of } \\
\text { February }\end{array}$ & 6 & $15 \%$ & 4 & T-Still births(5) & \multirow{2}{*}{$\begin{array}{l}\text { Recumbency, Opisthotonous, } \\
\text { Internal Vocalization. }\end{array}$} \\
\hline 5. & $\begin{array}{l}\text { 3rd week of } \\
\text { February }\end{array}$ & 7 & $17.5 \%$ & $4 \& 6$ & T-Abortions (2) & \\
\hline \multirow[t]{2}{*}{6.} & $\begin{array}{l}\text { 4th week of } \\
\text { February }\end{array}$ & 7 & $17.5 \%$ & $5 \& 7$ & $\mathrm{~T}-2$ died & Nervous signs, sudden death \\
\hline & Total & 40 & & & & \\
\hline
\end{tabular}

births and abortions. Table 2 shows the details of the pattern of outbreak in the affected farm

\subsection{Post Mortem Examination}

Necropsy was performed on ten goats and necropsy revealed good body condition and no obvious external lesions. The suprascapular lymph node was enlarged. The liver, kidney, heart and lungs were congested on PM examination. The small intestine was diffusely necrotized with presence of gas. Animals near death had normal or subnormal body temperature. Those dead were in lateral recumbency with opisthotonos posture. A presumptive diagnosis of enterotoxaemia was made. Multi-systemic haemorrhages of serosal surfaces, pericardial effusion was present with mild gastroenteritis.

There were extensive areas of hyperaemia in the cerebellum and in the cerebral cortex. Organ samples of heart, lung, liver, kidneys, small intestine, cerebellum and brain were collected in $50 \%$ glycerine buffered saline and $10 \%$ formalin for virological and pathological examinations, respectively. An aliquot of all the organ, tissue samples and swabs were collected in transport media on ice for bacteriological examination. Blood and tissue impression smears were also collected for staining and microscopic examination to identify the presence of any bacterial organisms. . Due to presence of diarrhoea, coccidial infection was also suspected and hence dung and intestinal scrapings were also collected for parasitological tests. A portion of the intestinal loop with its contents was also collected for identification of bacterial toxins. A total of 18-20 animals were segregated and jugular vein blood was collected and serum separated for various diagnostic purposes.

\subsection{Virological tests:}

Lung, lymph node and spleen of affected/dead kid was triturated, syringe filtered and used as antigen for counter immune electrophoresis (CIE) test along with positive control sera available at CUL (Roy et al., 2010). RNA was isolated from 10\% tissue suspensions using TRIZOL (Invitrogen, UK) following the manufacturer's protocol. Synthesis of c-DNA was carried out using first strand cDNA synthesis kit (Invitrogen, UK) method. The primers specific for PPRV-N Forward primer- 5'-TCT-CGGAAA-TCG-CCT-CAC-AGA-CTG-3' and Reverse primer -5'CCT-CCT-CCT-GGT-CCT-CCA-GAA-TCT-3') was used for amplification of 350bp region (Couacy - Hymann et al., 2002) The reaction mixture contained $12.5 \mu 1$ amplicon Red Dye Master Mix (Invitrogen, UK), $10 \mathrm{pM}$ forward and reverse primers each and DEPC water up to $25 \mu$ l. PCR was performed in an eppendorf thermocycler with the following conditions: Initial denaturation of $95^{\circ} \mathrm{C}$ for $5 \mathrm{~min}$ followed by 34 cycles each of denaturation at $94^{\circ} \mathrm{C}$ for $30 \mathrm{sec}$, annealing at $57^{\circ} \mathrm{C}$ for $30 \mathrm{sec}$, extension at $72^{\circ} \mathrm{C}$ for $30 \mathrm{sec}$ and a final extension of $72^{\circ} \mathrm{C}$ for $10 \mathrm{~min}$ and an infinite hold at $4^{\circ} \mathrm{C}$. The PCR products were electrophoresed on a $1.5 \%$ agarose gel in Tris EDTA buffer stained with ethidium bromide and visualized under UV light of Bio-Rad gel doc system, for the desired amplicon size against a100bp marker. 


\subsection{Bacteriological tests}

Totally twelve nasal swabs, each from five male and female animals and two from dead kids along with lung and heart blood swab were collected and subjected to isolation on nutrient agar and 5\% de-fibrinated sheep blood agar plates for cultural characterization. All isolates were stained with Gram's stain.

Bacteriological culture studies were performed prescribed by per Piatti et al. (2004). The tissue samples collected aseptically were transported to the laboratory within 1 to 4 hours of collection. Samples were rinsed with normal saline, macerated, diluted in PBS (1:10), and kept in a water bath with temperature maintained at $80^{\circ} \mathrm{C}$ for ten minutes in order to eliminate the non-sporeforming bacteria. Samples were then inoculated into tubes containing sterile Robertson's cooked meat medium (Smith \& Holdman, 1975) and maintained at $37^{\circ} \mathrm{C}$ for $48 \mathrm{hrs}$. A loopful from this suspension and its supernatant was plated on $5 \%$ defibrinated sheep blood agar plates with neomycin sulphate $(200 \mu \mathrm{g}$ $/ \mathrm{ml}$ ), on anaerobic agar plates and incubated anaerobically in an anaerobic jar using anaerobic gas generating packs Gaspack (® (Himedia ) at $37^{\circ} \mathrm{C}$ for $24-48$ hours (Wasinski, 2007)

The suspected colonies were identified by characteristic hemolytic activity, colony morphology, gram staining and biochemical tests. Biochemical identification like catalase, oxidase and lecithinase activity of selected strains was tested on TSA plates supplemented with egg yolk emulsion. Indole, MR-VP and Sugar fermentation tests were also done as described by MacFaddin (2000). Antimicrobial susceptibility test was done for all the bacterial isolate and the pattern of drug action was documented (Shamimuzzaman, 1999).

\subsection{Mice Inoculation Test}

To confirm the action of toxin, the mouse model biological assay was done. Abomasal and intestinal content of two kids were collected in sterile polythene covers and the ends tied with cotton thread so as to form a loop. The sample was immediately transported on ice to prevent protein degradation to lab. The intestinal contents were processed by centrifugation at 10,000 rpm for $20 \mathrm{~min}$ in a cooling centrifuge, after addition of chloroform. The exo-toxins that have been released by the Clostridial spp. in the intestine is of very low molecular weight and raises to the top (Fernandez-Miyakawa, 2003). This aqueous phase was pipetted out and stored in microfuge. The toxin supernatant is then used for mice inoculation bio-assay

\section{Results and Discussion}

In the present outbreak mortality of $2.5 \%$ was recorded in kids as compared to earlier report of $7.7 \%$ in kids during a natural outbreak of PPR in goats (Kumar et al., 2004). Clinical signs and gross lesions (Figure 1 and Figure 2) seen in the present outbreak were consistent with PPR outbreak as reported earlier (Chauhan et al., 2011). The tissue samples of lung and spleen were positive for PPRV by CIE using an antiserum raised against PPRV which confirmed that the primary cause of infection was Morbillivirus (PPRV). For confirmatory diagnosis RT-PCR was done using N gene specific primers. An amplification of 350 bp product (Figure7) confirmed the etiological agent as PPRV, in accordance with earlier reports describing the prevalence of PPRV specific antibodies (Balamurugan et al., 2012). In present study Tellichery breed were more affected as compared to the native Kanni breed which may be due to breed disposition. Also molecular studies will provide a better understanding about the viral determinants that play a role in virulence factors and pathogenicity of PPRV infection in goats which seems to vary from that of sheep during a natural outbreak.

Enterotoxaemia is reported almost every year from several part of India during the pre-monsoon season (Vinod Kumar et al., 2014). Epsilon toxin produced by $C$. perfringens is attributed to enterotoxaemia (Nasir et al., 2013). Pulpy kidney disease, the hallmark lesion in affected does occur rapidly due to hyperaemia in toxin damaged tissue was also seen (Chauhan et al., 2011). Complete identification of isolates by morphological and cultural characterization revealed that all isolates were Gram-positive spore-forming bacilli (Figure 6), produced double zone of hemolysis on sheep blood agar and were $C$. perfringens as described by Quinn et al. (2002) and the present work illustrated high rate of isolation (Abd El-Moez et al., 2013), which was in accordance with clinical signs and gross lesions observed (Figure 3; Figure 4 and Figure 5). The isolate was both catalase and oxidase negative and had lecithinase activity. It was negative for MR-VP and Indole tests and fermented sugars like Dulcitol, Dextrose, Sucrose, Lactose and Maltose.

Onset of the disease was sudden and animals were dead without any clinical signs which were in correlation with earlier reports that acute form of enterotoxaemia is noticed in young unvaccinated goats (Uzal \& Songer, 2008). In this study, $C$. perfringens type $\mathrm{D}$ was characterized by neurological disease involving perivascular edema of the brain which occurred in neonatal animals and also due to the lower trypsin levels that could be accounted for the sudden deaths and neurological signs. As per the ABST pattern the isolates were most sensitive to Gentamicin and Ceftrioxne, and drugs with an Intermediary action were Enrofloxacin, Streptomycin and Doxycycline Hcl while resistant drugs were Tetracycline, Amoxyclav and Penicillin.

Vaccination history of these animals was not clearly portrayed and warrants regular administration to prevent this important disease of small ruminants (Gowane et al., 2017). Thus this report summarizes the incidence of enterotoxaemia in stall-fed goats and 


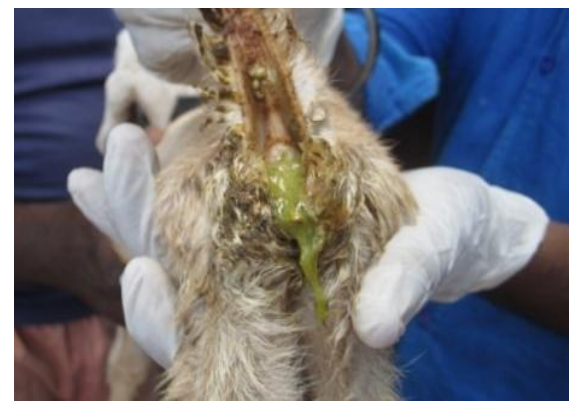

Figure 1 Tellichery kid showing profuse greenish diarhoea

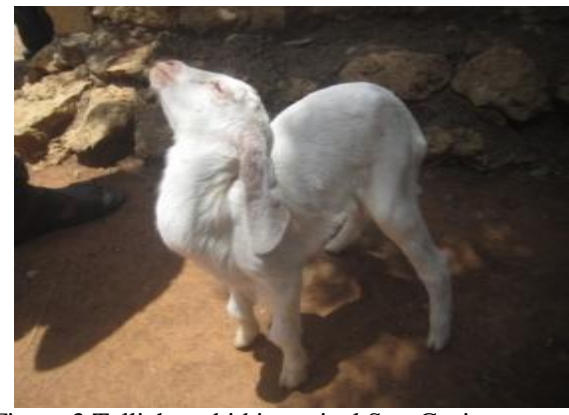

Figure 3 Tellichery kid in typical Star Gazing posture

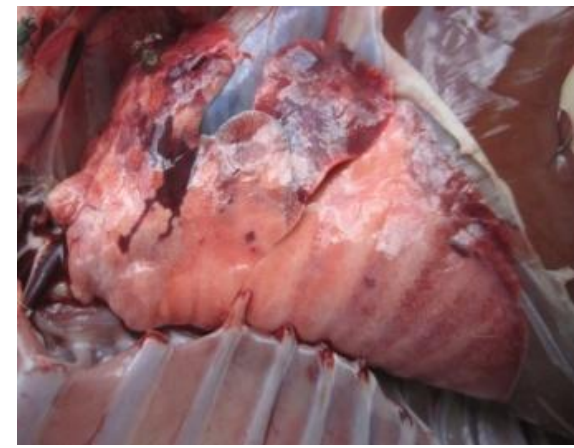

Figure 5 Lung showing rib marking and consolidation in the darkened areas

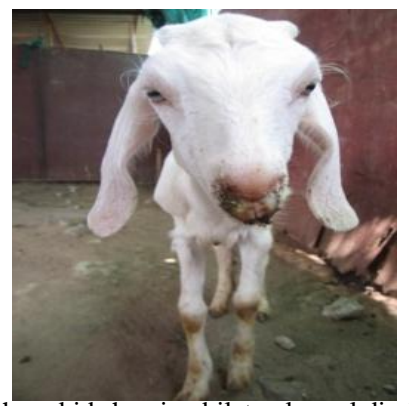

Figure 2 Tellichery kid showing bilateral nasal discharge and skin erosion

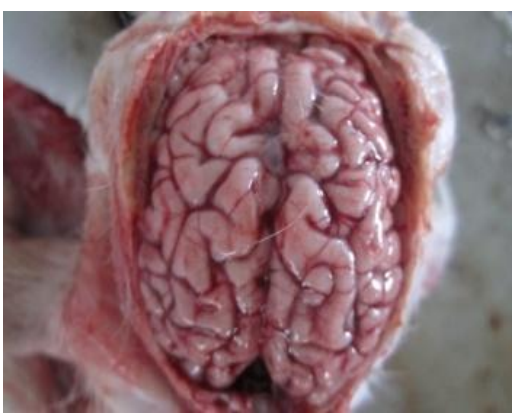

Figure 4 Hyperaemia of Brain tissue in an animal affected with enterotoxaemia

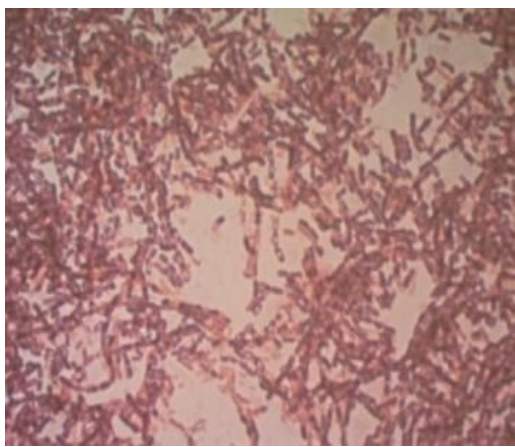

Figure 6 Large Gram positive Clostridial bacilli showing mid and terminal spores

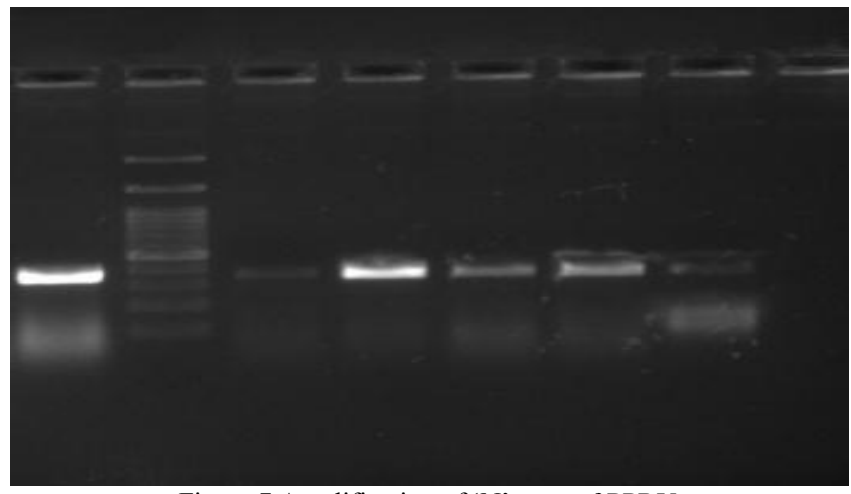

Figure 7 Amplification of 'N' gene of PPRV

Journal of Experimental Biology and Agriculture Science http://www.jebas.org 
kids after a primary PPR viral infection. However, in goats, the conventional vaccination produces lower and short lived titres than in sheep (Songer et al., 1996). So, the animals require booster doses every four months throughout their life after the first double vaccination. Thus, both the diseases can be kept at bay with regular vaccination and managemental strategies. The disease was more severe in young animals, aggrevated by poor nutrition, and concurrent infection with Enterotoxaemia outbreak.

\section{Acknowledgment}

Authors are thankful to TANUVAS for providing facilities for carrying the research work.

\section{Conflict of interest}

The authors declare that there is no conflict of interest.

\section{References}

Abd El-Moez SI, Ata NS, Zaki MS (2013) Bacterial Causes of Sudden Death in Farm Animals. Life Science Journal 10:11881201

All India Report of $19^{\text {th }}$ Liestock Census (2012) Department of Animal Husbandry, Ministry of Agriculture, New Delhi.

Balamurugan V, Saravanan P, Amab Sen, Jaushal Kishor Rajak, Gnanavel Venkatesan, Paramanandham Krishnamoorthy,Veerakyathappa Banuprakash, Rajkumar Singh (2012) Prevalence of Pestes des pettits ruminants among sheep and goats in India. Journal of Veterinary Science 13:279-285

Chauhan HC, Lambade P, Arnabsen AI, Dadawala PB, Ranaware BS, Chandel D, JoshiV, Patel SS, Kumar Pankaj, Shah NM, Kher HN (2011) The Use of Pathological and Histopathological Techniques in the Diagnosis of Peste des Petits Ruminants in India. Veterinaria Italiana 47:41-47

Couacy - Hymann E, Roger F, Hurad C, Guilou JP, Libeau G, Piallo A (2002) Rapid and sensitive detection of PPRV by a PCR assay. Journal of Virological Methods 100: 17-25.

Fernandez-Miyakawa ME, Uzal FA (2003) Clostridium perfringens isolate typing by multiplex PCR. The early effects of Clostridium perfringens type D epsilontoxin in ligated intestinal loops of goats and sheep. Veterinary Research Communications 3: 231-241.

Ferrarezi MC, Cardoso TC, Dutra IS (2008) Genotyping of Clostridium perfringens isolated from calves with neonatal diarrhea. Anaerobe 14: 328-331. doi: 10.1016/j.anaerobe.2008.12.001
Gowane GR, Akram N, Prince LL, Prakash V, Kumar A (2017) Genetic appraisal of serological response post vaccination against enterotoxaemia (ET) in Malpura and Avikalin sheep. Tropical animal Health and Production 49 : 867-873

Jemal D, Shifa Mand Kebede B (2016) Review on Pulpy Kidney Disease. Journal of Veterinary sciences and Technology $7: 36$

Kumar P, Tripathi BN, Sharma AK, Kumar R, Sreenivasa BP, Singh RP, Dhar P (2004) Pathological and Immuno histochemical study of experimental peste des petits ruminants virus infection in goats. Journal of Veterinary Medicine 51:153-159

MacFaddin JF (2000) Biochemical tests for identification of medical bacteria. Baltimore: Lippincott Williams \& Wilkins Pp. $1-450$.

Nasir AA, Yonnus M, Rehman MU, Lateef M, Rashid A, Ahmad R, Abbas M (2013) Molecular detection of C.perfringens type D alpha and epsilon toxin genes from various tissues in lambs. Pakistan Veterinary Journal 33: 492- 495

Piatti M, Ikuno AA, Baldassi L (2004) Detection of bovine Clostridium perfringens by polymerase chain reaction. Journal of Venomous Animals and Toxins including Tropical Diseases 10 :154-60.

Quinn PJ, Markey BK, Carter ME, Donnelly WJC, Leonard FC, Maguire D (2002) Veterinary Microbiology and Microbial Disease. Blackwell Science Ltd.

Roy P, Vairamuthu S, Thangavelu A, Chitradevi S, Purushothaman V, Koteeswaran A (2010) An outbreak of Peste des petits ruminants among Thelichery breeds of Goats. The International Journal of Applied Research in Veterinary Medicine 8:55-160.

Sawires YS, Songer JG (2006) Clostridium perfringens: insight into virulence evolution and population structure. Anaerobe $12: 23-43$.

Shaila M, Shamaki D, Forssyth M, Diallo A, Goatlay L, Kitching R, Barrett T (1996) Geographic distribution and epidemiology of peste des petits ruminants virus Virus Research 43:145-153.

Shamimuzzaman AHM (1999) Characterization of Clostridium perfringens isolated from goat and its antibiotic sensitivity, MS Thesis submitted to the Department of Microbiology and Hygiene, Faculty of Veterinary Science, Bangladesh Agricultural University, Mymensingh, Bangladesh.

Singh B, Bardhan D, Verma MR, Prasad S and Sinha DK (2014) Estimation of economic losses due to Peste de Petits Ruminants in small ruminants in India. Veterinary World 7: 194-199. 
Smedley JG, McClane BA (2004) Fine mapping of the N-terminal cytotoxicity region of Clostridium perfringens enterotoxin by sitedirected mutagenesis. Infection and Immunity 72 :6914- 23.

Smith LD, Holdman LV (1975) Anaerobic cocci. In: Thomas CC (Ed.), The pathogenesis of anaerobic bacteria. New York, Springfield, Pp. 91-107.

Songer JG (1996) Clostridial enteric diseases of domestic animals. Clinical Microbiology Reviews 9:216-34.

Uzal FA, Songer JG (2008) Diagnosis of $C$. perfringens intestinal infections in sheep and goats. Journal of Veterinary Diagnostic Investigation 20: 253-256

Uzal FA,Vidal JE, McClane BA and Guraj AA (2014) $C$. perfringens toxins involved in mammalian veterinary diseases.
Open Toxicology Journal 2:24-42

Vinod Kumar N, Sreenivasulu D, Reddy YN (2014) Prevalence of Clostridium perfringens toxin genotypes in enterotoxaemia suspected sheep flocks of Andhra Pradesh. Veterinary World 7: $1132-1136$

Wasinski B (2007) C. perfringens serotype A is incubated using Anoxomat ${ }^{\circledR}$ Mart Microbiol. Contribution of Clostridium perfringens type $\mathrm{A}$ with $\beta 2$ toxin gene in aetiology of porcine enteric diseases. A case report. Bulletin of the Veterinary Institute in Pulawy 51:509-13.

Wojdat E, Kwiatek K, Kozak M (2006) Occurrence and characterization of some Clostridium species isolated from animal feeding stuffs. Bulletin of the Veterinary Institute in Pulawy $50: 63-67$. 